\title{
Second International Conference on the Application of Micro-computers in Information, Documentation and Libraries
}

When the first International Conference on the Application of Mini- and Micro-computers in Information, Documentation and Libraries took place in March 1983 in Tel-Aviv, Israel *, the application of micro-computers in libraries, documentation- and information centers as well as in archives was rather an exception. In the meantime, micro-computers have been accepted world-wide as an integral part of these business operations. With their help, all kinds of processes can be simplified, improved, and accelerated. At the same time, microcomputers will change modes of operation and methods.

The discussion of this topic which has been started in Tel-Aviv is to be continued at the Second International Conference on the Application of Microcomputers in Information, Documentation and Libraries, in Baden-Baden, Federal Republic of Germany, from 17 to 21 March 1986.

The conference will be a platform for the international exchange of experience, pointing out tendencies of development, and the discussion of questions related to the application of micro-computers in libraries, in documentation- and information-centers, and in archives.

The Deutsche Gesellschaft für Dokumentation e.V. (DGD) has undertaken the responsibility of organizing the conference. The venue will be the Congress Hall in Baden-Baden - a city situated in the midst of the Black Forest, and one of the most beautiful ones in the Federal Republic of Germany.

Preliminary preparations have already begun. At present, it is intended that the sessions will deal with the following main topics:

1) description of existing systems, selection criteria for hardware and software,

* The proceedings of the conference (xx + 801 p., 118 figs., author and subject indexes), edited by Carl Keren and Linda Perlmutter, were published in 1983 by Elsevier Science Publishers (NorthHolland). 
future developments;

2) software requirements including data-base management systems, storage and retrieval systems, portability, downloading, data protection;

3) application in libraries including public and technical services and library management;

4) applications in information centers for specific disciplines-e.g. chemistry, physics, agriculture, social sciences, materials sciences;

5) special problems for applications in developing countries;

6) the application of micro-computers in electronic publishing, document delivery and knowledge processing;

7) education and training for librarians, information professionals and users.

It is also planned to organize symposia dealing with specific topics.

The language of the conference will be English. An exhibition of operating systems will also be part of the conference, and an extensive program of exhibitions and excursions for participants and accompanying persons will be arranged.

Intention to offer a paper should be indicated as soon as possible. The deadline for submission of title and brief outline is 28 February 1985.

For further information, please contact:

Deutsche Gesellschaft für Dokumentation e.V.

Westendstrasse 19

6000 Frankfurt am Main 1

Federal Republic of Germany

Tel.: (069) 747761 